\title{
Dictynna
}

Dictynna

Revue de poétique latine

$11 \mid 2014$

Varia

\section{Looking for Empedocles in Latin Poetry: A Skeptical Approach}

Joe Farrell

\section{(2) OpenEdition}

Journals

\section{Electronic version}

URL: http://journals.openedition.org/dictynna/1063

DOI: 10.4000/dictynna.1063

ISSN: $1765-3142$

\section{Electronic reference}

Joe Farrell, « Looking for Empedocles in Latin Poetry: A Skeptical Approach », Dictynna [Online], 11 । 2014, Online since 16 December 2014, connection on 10 September 2020. URL: http:// journals.openedition.org/dictynna/1063; DOI : https://doi.org/10.4000/dictynna.1063

This text was automatically generated on 10 September 2020

\section{(C) $\Theta \Theta \Theta$}

Les contenus des la revue Dictynna sont mis à disposition selon les termes de la Licence Creative Commons Attribution - Pas d'Utilisation Commerciale - Pas de Modification 4.0 International. 


\title{
Looking for Empedocles in Latin Poetry: A Skeptical Approach
}

\author{
Joe Farrell
}

In spite of the title I have given this paper, I would like to begin with some wild speculation. Is it possible that Empedocles was present at the very beginning of Latin literature? of course it is, and this is why: we happen to possess a fragment of Livius Andronicus' Odusia in which Mercury and Apollo are named: Mercurius cumque eo // filius Latonas (fr. 10 Mariotti). This is without question a version of Odyssey 8.322-23,

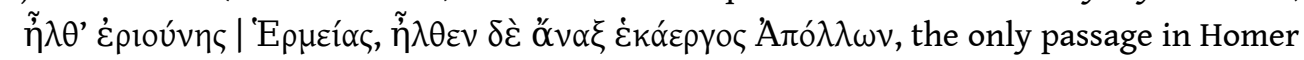
(other than the Hymns) where Hermes and Apollo appear together. ${ }^{1}$ The two gods are joking together about the revenge that Hephaestus has just taken upon the adulterous Ares and Aphrodite. That means Livius must have rendered the second song of Demodocus more or less as we have it in the Homeric Odyssey. But Livius was not a naïve interpreter of Homer. We know, for instance, that he frequently glosses the original so as to provide more information about such things as divine and human genealogy. ${ }^{2}$ We see that in this passage, where Apollo's name has mutated into a periphrasis, "the son of Latona." The result is to elevate the tone in a manner that agrees with characteristic patterns of expression in other examples of archaic Latin poetry. In most cases, the relevant genealogical information occurs elsewhere in Homer, but this is not always the case. For instance, Livius refers to the "Camena," i.e. Muse, as "daughter of Moneta" (sancta puer Monetas // filia docuit, fr. 12 Mariotti), i.e. of Mnemosyne. This is a detail that Livius did not find in Homer; its ultimate source is Hesiod's Theogony. Thus Livius is either combining aspects of the Homeric and Hesiodic traditions specifically or else situating his interpretation of the Odyssey within a larger context of Greek mythography as a whole. In addition, it is virtually certain that Livius used exegetical commentaries and sometimes incorporated their explanations of specific passages into his own work. Hermann Fränkel demonstrated this in another passage from Odyssey 8 (fr. 11 Mariotti) where Livius translates a scholiastic paraphrase of Homerinstead of Homer himself. ${ }^{3}$ So we may ask how Livius in this same book may have interpreted the story of Ares and Aphrodite. Did he, with his interest in genealogy, go beyond archaic Greek sources to acknowledge in any way that Mars and 
Venus were the divine ancestors of Romulus and Aeneas, respectively, and so of the Roman people as a whole ${ }^{4}$ Or did he consult a commentary that contained an exculpatory allegory like the one that survives among the E scholia on this passage, from which we learn that the adulterous pair actually represent Empedoclean Love and Strife, and their union the begetting of Harmony?

2 There is of course no positive indication that Livius took either of these steps, so we can hardly just assume that he did. But neither can we dismiss the possibility out of hand. Nor, when Cn. Naevius in his Bellum Poenicum invokes his Camenae as the nine harmonious daughters of Jupiter (novem Iovis concordes // filiae sorores, fr. 1 Stz.) can we assume that the adjective lacks an Empedoclean frame of reference. In another passage, which may have been crucial for the interpretation of the poem as a whole, Naevius offers us the first surviving ecphrasis in Latin literature, which depicts the most familiar and definitive emblem of cosmic discordia, a Gigantomachy (fr. 4 Stz.). ${ }^{6}$ Here again we can draw no definite conclusions, but neither can we exclude the possibility that Naevius presented the First Punic War as an Empedoclean disturbance of cosmic proportions, and his own poem as a monument to Roman victory as a form of harmony restored.

3 In what follows, I will try to refrain from speculation of this sort. I begin with these points for two reasons. First, I believe that too many critics simply assume that the earliest Latin poets were incapable of any sophistication at all, especially where philosophy is concerned. It is true that the remains of Livius and Naevius do not permit us to draw very many firm conclusions about such matters; but they do permit us to form hypotheses, and even if we cannot confirm them, we should not foreclose on the possibility that they may be valid on the basis of simple prejudice. Conversely, when we posit Empedoclean influence in later poetry, we often have little more concrete evidence than what we have just seen. What we do have is a much stronger belief in the intellectual sophistication of later poets and a more easily defended conviction that, once a particular ball has got rolling, it becomes difficult to stop. That is to say, once Empedocles got himself introduced into Latin poetry, perhaps it was impossible to get him out of it. This is a point of view with which I have some sympathy; but just as it is easy to be too skeptical about the very earliest poets, one could say that it is easy to be too credulous about their followers. So I will play advocatus diaboli (or perhaps

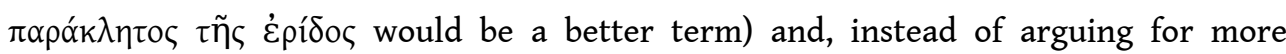
imagination in detecting the presence of Empedocles, I will argue in favor of greater caution.

4 Whatever we may think about Livius and Naevius, it seems likely that Empedoclean influence on Latin poetry began quite early. Quintus Ennius was clearly interested in philosophy, since he was the author of a prose work on the nature of the gods entitled Euhemerus and of a poem on natural science named for the Greek author Epicharmus, whose work "seems to have presented a blend of the docrines of Pythagoras and Empedocles, which is very much the blend that we find in Ennius." philosophically charged intervention must be the proemium of the Annales, where he relates how Homer appeared to him in a dream to expatiate on the transmigration of souls natural philosophy. ${ }^{8}$ More than this, it would be hard to deny that Ennius was interested in Empedocles specifically. Eduard Norden is chiefly responsible for the reconstruction of a famous and evocative passage in which a virago by the name of Paluda, born of hell and equivalent in some sense to a chaotic mixture of the four 
Empedoclean elements, rises out of the porous country that surrounds the sulphurous waters of the River Nar, takes the name of Discordia, and breaks open the gates of War. ${ }^{9}$ The episode belongs to book 7 of the Annales, but it is tempting to infer that its high Empedoclean color is just a more concentrated version of a theme that suffudes the entire poem. Certainly concordia is a theme of some import in book 1: the adverbial form concorditer apears in a fragment that Skutsch attributes to one of the Sabine women as she attempts to reconcile her own and all the Sabine fathers with their Roman sons-in-law. ${ }^{10}$ The tale of the Sabines would certainly have been susceptible to an Empedoclean treatment, with initial Strife being overcome by Love in such a way as to unite two rival states into a single, harmonious whole. Another passage, firmly assigned to book 2, is troubled by a partly unintelligible text, and Skutsch prudently refuses to specify the context to which it belongs. ${ }^{11}$ But most editors, focusing on the clearly legible and intelligible word concordibus, have assumed that it expresses the speaker's desire to maintain political harmony within the state, perhaps between the senate and the people, whatever the exact occasion may have been. ${ }^{12}$

5 To this extent, then, one could indeed infer that Empedoclean motifs amounted to a theme of some importance in the Annales, not only in its more obviously and programmatically philosophical portions, such as the dream of Homer, but also in certain episodes of civil strife and foreign conflict. And drawing this conclusion, however tentatively, might embolden us to extend Empedocles' influence to Ennius' conception of Rome's divine ancestors. The fact that Lucretius draws this connection at the beginning of his own poem, where Ennius and Empedocles figure as important predecessors, could be cited in support. ${ }^{13}$ But in any case, we can say pretty confidently that with Ennius' Annales Empedocles enters into Latin poetry with Love, Strife, and the four elements all in tow. The question is, was this first appearance merely a visit, or did Empedocles take up permanent residence in the Roman literary imagination? ${ }^{14}$

6 I would say, probably not. One can hardly be certain because we have practically no epic poetry between Ennius' time and that of Cicero, Catullus, and Lucretius. Characteristic motifs that were understood to be Empedoclean may have informed all the epics produced during the century or so that separated these authors. But we do not know. Putatively Empedoclean motifs appear with some frequency in the poetry that does survive from that period; but in no case does it seem likely that the motifs really have anything to do with Empedocles.

7 If we consider first the motif of the four elements, we find an elaborate treatment of it in book 28 of Lucilius' satires, which dates to about $131 \mathrm{BC} .{ }^{15}$ In that year the princeps senatus was, to Lucilius' disgust, one L. Cornelius Lentulus Lupus. In one fragment, Lucilius imagines someone as having to appear before a court presided over by Lupus.

Hoc cum feceris,

cum ceteris reus una tradetur Lupo.

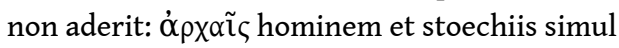

privabit, igni cum et aqua interdixerit.

duo habet stoechia, adfuerit anima et corpore

( $\gamma \tilde{n}$ corpus, anima est $\pi v \varepsilon \tilde{u} \mu \alpha$ ); posterioribus

stoechiis si id maluerit privabit tamen.

Once you've done this, he will be handed over to Lupus along with the others. If he doesn't appear in court, Lupus will deprive the man of his "original substances" and his "elements," too, when he has forbidden him access to fire and water. He has two elements, if he appears in body and soul (body is "earth" and soul "breath"); but he will forbid him access to the latter elements, if preferred. 
to appear before him on the appointed day might be met with the penalty of exile - or, in the traditional Roman formula, with deprivation of fire and water. Here Lucilius brings in the motif of the four elements, noting that even if Lupus deprived the accused of those two, he would have two left, earth and air, which Lucilius equates with body and soul; and in what seems to be an ironic concession to Lupus' non-existent sense of leniency and fair play, Lucilius notes that the defendant might be given the choice of forfeiting those elements instead - which apparently means, of foregoing exile in favor of immediate execution!

9 Few passages in Lucilius are as explicitly philosophical, or mock-philosophical, as this.

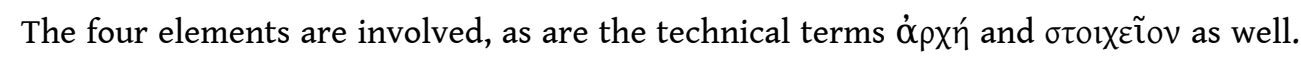
Lucilius went so far as to write the words out in Greek characters, as he also did with $\gamma \tilde{\eta}$ and $\pi v \varepsilon \tilde{v} \mu \alpha$, to ensure that readers would get understand his frame of reference. ${ }^{16}$ Without fuller context, his narrower point remains somewhat obscure: does it involve Lupus' own ridiculous philosophical pretensions, or does humor arise instead from a gap between Lupus' philistinism and the ludicrously grandiose concepts that Lucilius attributes to him? More important, however one answers that question, is whether Lucilius expected his readers to connect the passage to Empedocles in particular. The four-element theory was, after all, not exclusively identified with him, but had long since become the common property of many philosophical schools. ${ }^{17}$ So, in the absence of any reference to Empedocles in particular, it is only reasonable to assume that Lucilius adduces the motif as being emblematic of Greek philosophy in general and not of any philosopher in particular. ${ }^{18}$ If one is to judge from the evidence that we actually have, the burden of proof must rest upon anyone willing to answer the question, what is gained if we assume that the passage refers specifically to Empedocles? ${ }^{19}$

10 There are other and perhaps more interesting ways in which an elemental passage may be un-Empedoclean. In Accius's tragedy Medea, also known as The Argonauts, a simple shepherd describes the Argo when it came sailing down the river Ister. ${ }^{20}$ The sight is beyond his comprehension: he describes the ship as a kind of cosmic disturbance. Not unlike Ennius' Paluda, it requires the shepherd to enlist the elements in an effort to describe it properly:

tanta moles labitur

fremibunda ex alto ingenti sonitu et strepitu:

prae se undas volvit, vertices vi suscitat,

ruit prolapsa, pelagus respergit, reflat;

ita dum interruptum credas nimbum volvier,

dum quod sublime ventis expulsum rapi

saxum aut procellis, vel globosos turbines

existere ictos undis concursantibus

-nisi quas terrestres pontus strages conciet

aut forte Triton fuscina evertens specus

subter radices penitus undanti in freto

molem ex profundo saxeam ad caelum eruit

11 Note that the ship starts out as a solid thing, a moles, that roils the waters in its path, creating whirlpools and a watery spray that it blows backwards as it goes. Then splashing and mist suddenly give way to cloudburst: the Argo is compared to an interruptum...nimbum. Then a more sudden shift makes it a saxum caught up by wind and storm, or a waterspout caused by clashing waves, or an earthquake or some other 
extraordinary land event caused by forces below the sea. The Argo, then, presents an image of cosmic disarray: as it moves it sets all the elements into motion as well, causing each to abandon its proper place. ${ }^{21}$ So Accius' shepherd speaks, unwittingly, no doubt, in words that for the knowing listener characterize the first ship as an elemental disturbance of cosmic proportions.

12 Here it is important that Accius' play was presumably an adaptation of some earlier Greek model, although we have no idea what that might have been. But unless he is freely inventing here, it is likely that the elements already played a role in his source. Indeed, it is even possible that these elements were more specifically Empedoclean in the source than they seem to be in Accius. And since Accius' shepherd is describing the Argo, we can add that Empedoclean motifs certainly do play a role in key passages of Apollonius' Argonautica..$^{22}$ Accius, for his part, was not only Rome's greatest tragic poet, but also one of the great literary historians of his time. ${ }^{23}$ We have no positive indication that he knew and imitated Apollonius, but it would be rash to conclude that he cannot have done so. The possibility must exist, then, that Accius composed this passage with some reference to Empedocles, inspired either by his primary source, or by Apollonius, or even by some combination of the two. Finally, Cicero, who preserves this fragment of Accius in his De natura deorum, does so in a way that makes it seem likely that readers of his own time at least thought that it contained some philosophical import. ${ }^{24}$ Let us then, for the sake of the argument, suppose that it does. The question is, how strong is the possibility that Accius was thinking of Empedocles?

13 I think the possibility is real. But, paradoxically, if Accius was thinking of Empedocles in particular, he seems to have taken steps to hide that fact. This would be all the more true if Accius were thinking of Apollonius or if Accius' primary source clearly indicated its debt to Empedocles. The reason I say this is very simple: because the elemental character of Accius' universe as we see it in this passage is triune. ${ }^{25}$ This is to say, the elements that the Argo confounds are those of earth, water, and air, with fire nowhere to be found. Indeed, fire is almost conspicuous by its absence, since the kind of violent storm that Accius' shepherd envisions is, in poetry, almost always accompanied by lightning, i.e. the fiery element. One could choose almost any literary storm at random and expect to find all four elements represented. It is true that there are sometimes good reasons to think that Empedocles is a factor even in certain passages where fewer than four elements appear, and we may entertain that possibility here. ${ }^{26}$ But the three elements that Accius does name may point specifically to the Roman concept of the tria regna or three realms of earth, sea, and sky. ${ }^{27}$ We should therefore ask whether Accius actually suppressed any reference to the fourth element specifically in order to present a version of the shepherd's ecphrasis that would speak more forcefully to his Roman audience. And so, we may ask, do we have here some evidence of resistance to Empedoclean influence in early Republican literature?

14 So far I have been considering the four elements; now I turn to the relationship between Love and Strife or, as Ennius calls them, concordia and discordia. These and related words are not uncommon in Republican literature; but in that context they seem to have little to do with Greek philosophy of any sort, let alone with Empedocles. The etymology of concordia would seem to suggest that its root meaning was likemindedness between or among individuals, and comic usage tends to support this idea: in Plautus and Terence, contexts where these words occur ususally concern marital harmony or good relations between friends and relatives. ${ }^{28}$ But some passages suggest 
that harmonious personal relations are the basis of political stability. ${ }^{29}$ In tragedy there is a more pronounced tendency to link marital or familial harmony to the welfare of the state, as is easier to do in a world of heroic kingdoms instead of the city states of New Comedy. ${ }^{30}$ We noticed that the same thing is true in Ennius, as well. It may therefore be that frequent use of concordia and discordia in political contexts converted these words into quasi-technical terms of public discourse. The orations of Cato indicate that already by the mid-second century discordia is the mot juste for civic dissension. ${ }^{31}$ More ominously for the Republic, not long after Cato's death, the consul of 121, L. Opimius, supervised the illegal execution of C. Gracchus and about three thousand of his followers, then celebrated the restoration of civic order by erecting a Temple of Concordia (which immediately and for centuries thereafter was referred to as the Temple of Discordia). ${ }^{32}$ This is the first such temple for which we have probable archaeological evidence. But the literary tradition, at least some of which may have been invented during this period, speaks of earlier structures that were also represented as responses to civil strife. ${ }^{33}$ And when we inspect the much more voluminous evidence provided by first-century writers like Cicero and Sallust, both concordia and discordia are everywhere, and no indication that either writer regards them as related to Empedocles or any other philosopher, rather than simply as among the most familiar slogans of Roman political life.

15 Against such a background, then, how can any occurrence of the four-element motif or of Concord and Discord be regarded as specifically Empedoclean, rather than generally philosophical on the one hand or simply political on the other? I believe there is a relatively simple answer to this question, and that it comes from the bizarre intersection between mythology, philosophy, and the appropriation of Venus as a political emblem in the late Republic.

Venus had been worshipped in Rome since at least $295 \mathrm{BC} .{ }^{34}$ But her political relevance became much greater in 217 when the cult of Aphrodite Aineias was imported to Rome under the guise of Venus Erycina. This was a diplomatic and strategic maneuver designed to confirm an alliance between the Romans and the people of Segesta in Sicily, who worshipped the goddess at a cult site on Mt. Eryx. Because the move was justified on the basis of shared Trojan ancestry, it bears a good deal of further cultural import in that it strengthens this element of Roman national mythology. ${ }^{35} \mathrm{~A}$ further step was taken by L. Cornelius Sulla in $86 \mathrm{BC}$ when he claimed Venus as the patron of his military success. ${ }^{36}$ The next step occurred in 68 when Julius Caesar pronounced his famous funeral oration over the body of his aunt Julia Marii, boasting that the Julian gens in particular was descended from Venus through Aeneas and his son Iulus. ${ }^{37}$ Then, in the mid-fifties, Pompeius Magnus built his magnificant theater complex in celebration of his victories in the east. The events leading up to this decisive event require a brief excursus. First, I must mention the lex Gabinia of 67, which assigned Pompeius imperium over the entire Mediterranean and over all lands within fifty miles of the sea - in effect, then, over the entire world. For a man who already styled himself as Magnus in

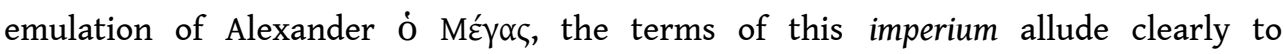
Alexander's own designs for world dominion. Using this power, Pompeius dealt quickly with the problem of piracy, which was the main point of his extraordinary command, and then turned to the administration of Cilicia and Pamphilia before taking charge of the third war between Rome and King Mithridates of Pontus under the lex Manilia of 66. Over the next three years Pompeius used this command to consolidate and add to Roman territory throughout the east as far as the Caspian Sea. He could thus, as a result 
of victories won under his auspices between 66 and 63, claim to have extended the boundaries of Rome's empire virtually to the limits of the known world, realizing or even surpassing Alexander's dream of creating a world-state of cosmic dimensions. According to Plutarch (Pompeius 45.5), the triumph that Pompeius celebrated in 61 in virtue of his defeat of Mithridates was designed to make exactly this point. And it was on this occasion that he vowed the vast theater complex, which was not dedicated until 55.

17 This brings us to the end of our discursus, because the centerpiece of Pompeius' theater complex was a temple dedicated to new cult, that of Venus Victix. The statement that this complex made was that Pompeius had established a Roman peace throughout the world under the patronage of this goddess. The new cult may thus have been intended to assert Pompeius' claim to the mantle of Sulla, who years before had sponsored the young Pompeius' precocious arrival into public life; it may also have advertised Pompeius' dynastic marriage to the daughter of Julius Caesar, a living descendant of Venus. But in 54, the very year after Venus Victrix was dedicated, Julia died; and in the following year M. Licinius Crassus, the third member of Pompeius and Caesar's coalition, met his end at Carrhae. As antagonism between Caesar and Pompeius grew, Caesar planned to build his own temple to Venus Victrix. ${ }^{38}$ After his victory over Pompeius at Pharsalus, he changed his mind and instead dedicated a temple to Venus Genetrix in the Forum Iulium. ${ }^{39} \mathrm{He}$ himself would not live to finish it, but his adoptive son would complete and complement it by building the adjacent Forum Augustus, the centerpiece of which would be a magnificent temple dedicated not to Venus, but to Mars. ${ }^{40}$

18 The general point here is that Venus became during the first century $\mathrm{BC}$ an unprecedently important political symbol in Rome. Her role as ancestor of the Roman people, and particularly of the gens Iulia, is obviously key to this development. But her amorous relationship with Mars, father of Romulus, favored Venus' rise to prominence, as well. Love and war, dynastic marriage, heroic genealogy, and many other aspects of this relationship all played their parts. And although we cannot say exactly how or when the specifically Empedoclean allegory of Venus and Mars as Love and Strife entered the political realm, it is clear from the poetry and iconography of the Augustan period that it did so. ${ }^{41}$ And some poetry from as early as the fifties, most outstandingly Lucretius' proemium to De rerum natura, is convincingly explained in just these terms. ${ }^{42}$ Therefore, between the time of Lucretius and that of Ovid or Manilius, epic meditations on cosmos and imperium, the elegiac duality of love and war, and numerous other areas of poetic discourse in late Republican and Augustan times, all developed in an environment that was extremely propitious to the exploitation of Empedoclean imagery.

19 That said, similarly favorable conditions simply did not exist before the mid-first century. The cult of Venus Genetrix, as we have seen, owes its origin to the importation of Aphrodite Aineias as Venus Erycina in 217. It is obviously quite possible that Livius Andronicus produced his epic before that watershed event, and there is no reason to assume that Venus had any particular importance in his Odusia, particularly as the mother of Aeneas. For Naevius, this genealogy was important, but we still cannot assume that Venus had been integrated into the Roman imaginary to anything like the extent that she would be later on. In particular, we must refrain from making assumptions about how Naevius regarded Venus and Mars as lovers, even in a Homeric 
sense, let alone an Empedoclean one. Not to do so is to impose an Augustan-centered, teleological interpretation on the evidence. Such an interpretation is by no means impossible. But if we too easily assume that it is probably correct, we could easily blind ourselves to other possibilities that are actually no less so. conception of Mars and Venus as divine forces held in balance to create conditions of universal government under the aegis of Rome appears to have been much less salient than it had been for the previous half-century or so. One of the latest passages of Ovid's Fasti celebrates Tiberius' dedication of a new temple to Concordia Augusta on the Capitoline, where Opimius' anti-Gracchan temple had formerly stood, as well as a smaller shrine dedicated by Livia to the same goddess. ${ }^{43}$ The point of renewing the Concordia cult at this time - Tiberius' dedication took place in A.D. 10 - had to do with harmony not throughout the body politic, but within the imperial family, since it was upon such harmony that any hope for a peaceful succession depended. Once this transition had taken place, however - once, that is to say, the Julian era came to an end and was replaced by the Claudian - Augustus' own divine ancestry was presumably a less compelling vehicle for propaganda than it had once been. And, I would suggest, we see a corresponding loss of Empedoclean focus in the literature and imagery of the Neronian period..$^{44}$ This is even more the case in the Flavian period and after. ${ }^{45}$ Although Vespasian and his successors all assumed the titles Caesar and Augustus, they did not become members of the gens Iulia and were not descended from Venus. ${ }^{46}$ Romulus of course remained the son of Mars, and Rome's empire remained ideologically coextensive with the oecoumene. But the motif of the four elements seem to have lost any specifically Empedoclean by the end of Augustus' reign, just as the union of Venus and Mars no longer signified in the way it had done under the ascendency of the the Iulii.

21 In conclusion, then, I believe that caution is warranted. It is certainly true that Empedoclean motifs become available to Roman poets fairly early in Latin literary history. Availability and relevance, however, are different things; and it seems to be primarily in the last half of the first century $\mathrm{BC}$, thanks to a remarkable concatenation of political, dynastic, intellectual, and artistic circumstances, that Empedocles achieved such importance in all these fields. The poets of that time were exceptionally skillful at making their own work look like the culmination of what earlier ages had always been trying to achieve, and their use of Empedocles seems to be no exception to that rule. But I believe that we need more and solider evidence before we can agree with them; and in any case, it appears that even if the four elements maintained their hold on the literary imagination of the early imperial period, their association with Empedocles was less durable. Under the circumstances, I believe it makes sense to speak of Empedoclean moments or revivals rather than of a continuous tradition that informs the entire history of Latin literature. ${ }^{47}$ 


\section{BIBLIOGRAPHY}

Anderson, J. C. 1984. The Historical Topography of the Imperial Fora. Collection Latomus 182. Brussels.

Broughton, T. R. S. B. 1951. The Magistrates of the Roman Republic. Vol. 1. Cleveland.

Courtney, E. 1993. The Fragmentary Latin Poets. Oxford.

Degl'Innocenti Pierini, R. 1980. Studi su Accio. Florence.

Dufallo, B. 2013. The Captor's Image: Greek Culture in Roman Ecphrasis. New York.

Farrell, J. 2013. “Camillus in Ovid's Fasti. Augustan Poetry and the Roman Republic. Oxford. 57-88.

Farrell, J. 2014. "Philosophy in Vergil." The Philosophizing Muse: The Influence of Greek Philosophy on Roman Poetry. Ed. Myrto Garani and David Constan. Cambridge: 61-90.

Fraenkel, E. 1931. "Livius Andronicus.” RE. Suppl. 5. 598-607.

Fränkel, H. 1932. “Griechische Bildung in altrömischen Epen, 1. Livius Andronicus als Übersetzer," Hermes 67: 303-11.

Gale, M. 2007. "Lucretius and previous poetic traditions." The Cambridge Companion to Lucretius. Ed. S. Gillespie and P. Hardie. Cambridge: 59-75.

Galinsky, G. K. 1969. Aeneas, Sicily, and Rome. Princeton.

Garani, M. 2007. Empedocles redivivus: Poetry and Analogy in Lucretius. New York.

Gruen, Erich. 1992. Culture and National Identity in Republican Rome. Ithaca.

Ham, C. T. 2013. "Empedoclean Elegy: Love, Strife, and the Four Elements in Ovid's Amores, Ars Amatoria and Fasti." Diss. University of Pennsylvania. Philadelphia.

Hardie, P. 1995. “The Speech of Pythagoras in Ovid Metamorphoses 15: Empedoclean epos," CQ 45, 201-14.

Hardie, $P$. Virgil's Aeneid: Cosmos and Imerium. Oxford.

Knoche, U. 1958. “Über die Aneignung griechischer Poesie im älteren Rom.” Gymnasium 65: 32141.

Leo, Friedrich. 1912. Plautinische Forschungen. 2d. ed. Berlin.

Lloyd, G. E. R. 1987. The Revolutions of Wisdom. Berkeley.

Nelis, D. 2001. Vergil and the Argonautica of Apollonius Rhodius. Leeds.

Norden, E. 1915. Ennius und Vergilius: Kriegblider aus Roms großer Zeit. Berlin.

Schilling, R. 1954. La Religion romaine de Vénus depuis les origines jusqu'au temps d'Auguste. Paris.

Sedley, D. 1998. Lucretius and the Transformation of Greek Wisdom. Cambridge.

Taylor, L. R. 1941. “Caesar's Early Career.” Classical Philology 36: 113-32.

van Raalte, M. 2010. “The Nature of Fire and Its Complications: Theophrastus' De Igne 1-10.” BICS 53: 47-97.

Warmington, E. H. 1938. Remains of Old Latin. Vol. 2: Lucilius, The Twelve Tables. Cambridge, MA.

Wiseman, T. P. 1995. Remus: A Roman Myth. Cambridge. 
Zanker, P. 1968. Forum Augustum. Tübingen.

\section{NOTES}

1. The closest the two gods come to one another apart from this passage is in the theomachy of Il. 20.54-74, where Apollo pairs off against Poseidon (68) and Hermes, interestingly, against Leto (72).

2. Leo 1912: 91, Fraenkel 1931: 603-7, Mariotti 1952 (1985): 33, Knoche 1958: 333 (with reference to the "senatorischer Stil" familiar from archaic inscriptions).

3. Fränkel 1932: 306-7; cf. Mariotti 1952 (1985): 22.

4. Aeneas' divine parentage of course known to Homer (Il. 2.819-21, 5.247-48, 20.208-9; cf. Hymn 5.191-99, 256-91) as well as to Hesiod (Theog. 1008-10). The earliest unambiguous assertion that Mars was the father of Romulus and Remus is found in a late third or early second century inscription from Chios (SEG 16.486), butLivy's report (10.23.11-12) of a monument erected by Q. Ogulnius, consul of $296 \mathrm{BC}$, may indicate that the story was already current before Livius' time; for this interpretation, see Wiseman 1995: 72-76.

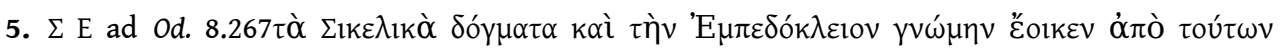

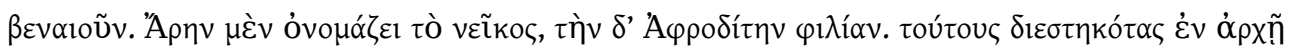

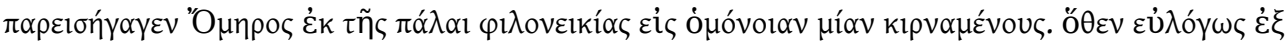

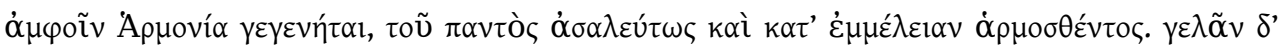

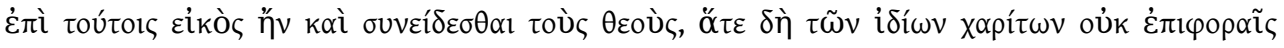

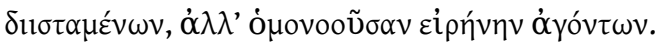

6. On this passage see Dufallo 2013: 16-20, with further references.

7. Courtney 1993: 30, with his collection of and commentary on the fragments, 32-38.

8. See Ann. 2-11 Sk. I agree with Skutsch's revisionist intrepretation of line 5 against Flores (2002: 2, 49 ad fr. xliii) and earlier editors.

9. Norden 1915: 10-19; see Ann. 220-26 Sk. 240-46 Flores.

10. aeternum seritote diem concorditer ambo, Ann. $101 \mathrm{Sk} .=109$ Flores. The verb sero is remarkable here: the metaphor seems to involve the continuous and repetitive planting seeds in a row, so that the Romans and the Sabines will enjoy a lasting series of harmonious days, rather than envisioning a single, originary event and its eventual results (as in the metaphor of "sowing the seeds" of civic discord and similar social ills, which is very common in later writers, e.g. Liv. 3.40.10), although perhaps one should also infer that civic harmony from these small beginnings will grow great.

11. ingens cura †mis cum $\dagger$ concordibus aequiperare, Ann. $133 \mathrm{Sk}$.

12. Esposito (in Flores 2002: 2, 73 ad Ann. 134) follows Vahlen in attributing the line to a speech made by the lone surviving brother among the Horatii following his victory over the Curiatii.

13. Sedley 1998: 1-34, especially 22 and 33; Gale 2007; Garani 2007.

14. Hardie 1995; cf. (e.g.) Nelis 2000, 2001: 96-112, 345-64.

15. The fragment is quoted by [Probus] in Verg. Ecl. 6.31 as from "Lucilius in XXVIII satyrarum." On the dating of the satires see Warmington 1938: vii-xv.

16. A. Chahoud, "The Roman Satirist Speaks Greek," Classics Ireland 11 (2004), 1-46.

17. After Empedocles, the four-element theory is picked up by Aristotle and then by the Stoics Chrysippus and Zeno. On the history of the theory see Lloyd 1987: 226-30.

18. It was in fact Epicurus who likened the relationship of body and soul to that of earth and

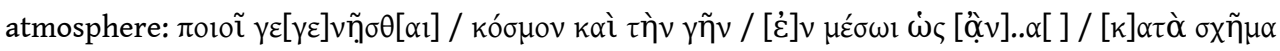

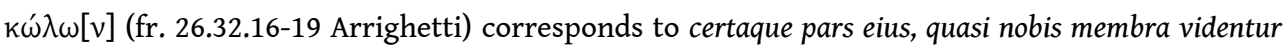
(DRN 5.549); cf. Bailey (1947) 1756-1757. 
19. One attraction of regarding the passage as specifically Empedoclean, of course, is that doing so helps to fill in the large chronological gap between Ennius and Lucretius, poets who have been taken as participants in a tradition of "Empedoclean epos." But such an argument involves circular reasoning; and in any case, Lucilius composed this satire in trochaic septenarii, one of three meters (including dactyllic hexameters) found in books 28 and 29. It therefore dates from a period when he was redefining the generic associations of satire by abandoning the dramatic meters that he had used exclusively in books 26-27 for the epic meter, which he would then use exclusively in books 30 and books 1-25. From this, it is evident that any putative association between this fragment and Empedocles did not depend on involve a further association between Empedocles and epos.

20. Accius $381-96$ Warmington $\approx 467-82$ Dangel.

21. There may even be a suggestion of return to primordial chaos in the shepherd's first words, tanta moles labitur. Their primary, intended meaning is of course, "A really huge, massive thing is gliding along." But Ovid would famously use moles to describe primordial Chaos (rudis indigestaque moles, Met. 1.7), and elsewhere it often refers to any great structure or machine (L\&S I.B.3-4). Meanwhile, the verb labor can denote either the smooth, even motion of such things as ships and stars or else the collapse of great structures and machines (L\&S II.B.3).

22. Nelis 2000, 2001: 96-112, 345-64.

23. On Accius' Didascalica, see Degl'Innocenti Pierini 1980: 58.

24. De nat. deor. 2.89. one of his interlocutors, Q. Lucilius Balbus, quotes the Accius passage in order to illustrate a particular point. The shepherd, as Balbus points out, is amazed and confused by what he sees. It makes no sense to him. But eventually, as Balbus goes on to say, he realizes that there are men aboard it and that the thing is not a symptom of elemental disturbance but a device that is subject to human control. "In just this way," Balbus continues, "the philosophers, whenever it was that their initial contemplation of the universe began to disturb them, must later have understood, when they had seen that its movements were bounded and regular and that all things were contained within fixed ranks and by a changeless consistency, that there was in that heavenly and godlike residence not merely some inhabitant but a governor and a regulator and as it were an architect of so great a construction and so great a piece of work." of course, Balbus' use of Accius' play to illustrate a philosophical point that concerns the structure of the universe does not guarantee, by any means, that we may regard Accius himself as alluding to philosophy in these lines. For what it is worth, though, Balbus represents a Stoic, not an Empedoclean, position in the dialogue.

25. This in itself does not mean that natural philosophy is irrelevant to the passage. On the problems that fire presented to natuaral philosophers see (e.g.) Theophratus, De igne 1-10 with van Raalte 2010.

26. In this connection, it is worth noting that Accius uses the word radices ( $95 \mathrm{~W}, 81 \mathrm{D})$, which could be a calque on Empedocles' $\dot{\rho}_{1} \zeta \omega \operatorname{\omega } \mu \tau \alpha \alpha$ (fr. 6, Aetius 1.3.20), his word for the four "elements"

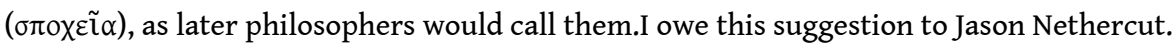

27. Other poets sometimes allude knowingly both to this conception of the cosmic order and to the one based on the four elements. In Eclogue 6, the Vergilian narrator tells that Silenus began his song by singing of "how the seeds of earth and air and sea had been forced together through the great void along with those of pure fire..." (30-32).

Namque canebat uti magnum per inane coacta

semina terrarumque animaeque marisque fuissent

et liquidi simul ignis....

Here Vergil carefully disposes the tria regna in such a way that they make up a single, beautifully formed, satisfyingly whole hexameter line, but then disrupts the perfect symmetry of his creation by adding the fourth element. In so doing, he renders, very closely indeed, a pasage 
from the cosmogony sung by Orpheus in Apollonius' poem in which an Empedoclean presence is very much in evidence:

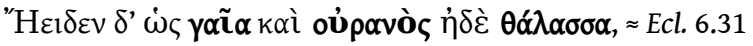

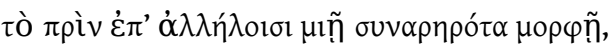

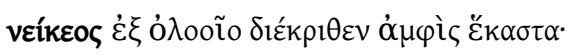

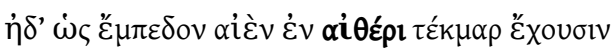

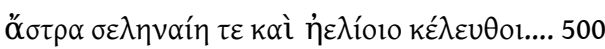

He sang how earth and sky and sea, previously joined together upon one another in a single form, were all separated as a result of baleful strife; and how the stars and the moon and the paths of the son continually keep their appointed place in the ether.

Crucially, however, Apollonius' allusion to Empedocles depends not only on the addition of fire or ether to the other three elements, which does not occur until four additional lines have passed

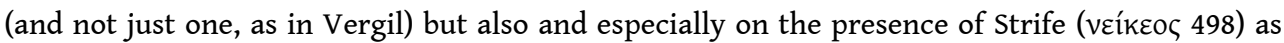
well. It is really the combination of the four elements with the motif of Love and Strife that marks the passage as specifically Empedoclean. Vergil does not speak of Love or Strife, and his language (especially semina 31) of course points to a characteristic feature of Epicurean physics as expounded by Lucretius: see Farrell 2014: 63-66.

28. concor- 7x, plus Caecilius pall. 109, Afranius tog. 53; discor- 5x plus Atta tog. 21. Ennius' concorditer (Ann. $101 \mathrm{Sk}$ ), which Skutsch regards merely as "characteristic of early Latin" (1985: 250) also appears in Curculio (264) in an interesting scene of temple incubation that would, however, be difficult to trace back to Empedocles.

29. It even seems possible that many comic references to marital, familial, and interpersonal concordia and discordia already bear some symbolic political import.One passage from Aulularia (481, ut indotatas ducant uxores domum, / et multo fiat civitas concordior, / et invídia nos minore utamur quam utimur) draws an explicit connection between marital and civic harmony.

30. The plot of Pacuvius' Hermiona revolved around a quarrel between Orestes and Neoptolemus over the right to marry Menelaus' daughter and so to rule over Sparta; thus the theme of marital concorditas and discorditas (words that Pacuvius coins in order to emphasize the theme: see trag. 183,193 Warmington $\approx 131,136$ Schierl) in this play has clear political dimensions. In a tragedy by Ennius, (trag. inc. 310 Jocelyn: see pp. 416-417), someone prays to the gods who have power over the worlds above and below that some number of other characters who are not named might be reconciled to the point where they might begin to think about concordia. If, as some mss. indicate, the speaker is Thesprotus, then the play is Thyestes and the discordant characters are the title character and his brother Atreus; if, as others suggest, it is Cresphontes, then the identity of the parties to be reconciled is uncertain, along with much else concerning the , In Accius' Phoenissae someone worries that discordiae between the sons of Oedipus will destroy a prosperous state (trag. 590 Warmington, 567 Dangel).

31. His dissuasio legis Iuliae de feneratione of 191 or $190 \mathrm{BC}$ speaks of discordia as a result of money leanding (fr. 57 Malcovati).

32. Plut. C. Gracch. 17.6, August. De civ. D. 3.25.

33. Farrell 2013: 61-68, 76-81.

34. The aedes Veneris Obsequentis, begun by Q. Fabius Maximus Gurges, curule aedile (according to Broughton 1951: 178) in 295 and financed out of fines paid by women caught in adultery,is the oldest known temple of Venus in Rome (Livy 10.31.9, Servius in Aen. 1.720).

35. Galinsky 1969: 169-90, Gruen 1992: 46-47.

36. Sulla's adoption of the agnomen Felix (or, in Greek, "Epaphroditos" according to Plut. Sulla 34.3-4) was evidently associated with a cult of Venus Felix (CIL 6: 781-82 = ILS 3166, 8710). See Schilling 1954: 272-95.

37. Suet. Iul. 6, Plut. Caes. 5.1; cf. Taylor 1941: 122-23.

38. According to App. $B C 2.68$. 
39. App. BC 2.102.

40. On the Forum Iulium see Anderson 1984: 39-63. On the Forum Augustum see Zanker 1968.

41. In poetry, for instance, Vergil's replacement of the second song of Demodocus, on Aphrodite and Ares, with the song of Iopas, a cosmological song, is taken to reflect the Empedoclean allegory of the divine pair as Love and Strife: see notes 13 and 14 above. Venus and Mars are prominently fetured at the center of book 1 of Ovid's Amores (poems 7-9) and of the Ars Amatoria (2.425-92): see Ham 2013: 121-48, 177-213. The urbanistic relationship of the Forum Iulium, with the Temple of Venus Genetrix, and the Forum Augustum, with the temple of Mars Ultor (its pediment graced by a sculptural group in which Venus and Mars flanked Divus Iulius) is based on the dynatic relationship of Venus to the gens Iulia and of Mars, through Romulus, to the Roman people as a whole, but the cosmic significance of the two divinities speaks to Roman (and Caesarian) pretentions to universal empire.

42. Garani 2007: 37-43, with further references.

43. Cf. Farrell 2013.

44. Nero's blood relationship to his Julio-Claudian predecessors was tenuous, and he did not emphasize Venus as a divine ancestor. Among Neronian writers, Seneca refers frequently to the four elements, but what he says is most convincingly understood in terms of the author's predominantly Stoic beliefs. Cosmic references in Lucan share a similar, though non-doctrinaire, Stoic perspective.

45. See for instance Valerius Flaccus' disparaging reference to the "Phrygian" dynasty that preceded the Flavians (Arg. 1.9). In Statius' Thebaid, after Jupiter sends Mars to unleash war on Thebes (3.218-59), Venus intervenes with Mars in the name of their child Harmonia (271), i.e. Concordia, wife of Cadmus and thus common ancestress of the Thebans, and Mars delays his onslaught in deference to this plea (260-323). The episode is rich with Empedoclean possibilities, which Statius does little or nothing to exploit.

46. Vespasian assumed the titles of Caesar and Augustus, but did not become a member of the gens Iulia. His signature urban project, the Templum Pacis, advertised the restoration of peace after the civil war of $69 \mathrm{AD}$ and the Judaean war of $66-70$, but the structure is quite separate, even pointedly so, from the more evidently "Empedoclean" Forum Iulium/Forum Augustum complex.

47. The paper that Hans Berndorff presented at the Geneva conference on Empedoclean elements in the ps.-Vergilian Moretum illustrated well the nature of such revivals. The sheer incongruity between that poem's subject matter and any philosophical frame of reference in this poem points clearly to parody, perhaps of Vergil's own Empedoclean pretensions, in the eyes of some imitator.

\section{ABSTRACTS}

Motifs such as "harmony," "concord," and "the four elements" are very common in Latin poetry, but they may not always indicate a specifically Empedoclean. Words like "concordia" and "discordia" appear frequently in contexts where domestic or civic harmony and disharmony are at issue, but where philosophy of any sort is not. The four elements generally do occur in contexts that are philosophical, whether in a direct, metaphorical, or even a parodic sense; but the conception of the physical world as comprised by earth, air, fire, and water was common to many philosophical schools, including Stoicism, which was much more familiar than Empedocleanism as a philosophical sect to Romans of all periods. Specifically Empedoclean 
motifs often do appear during the last half of the first century BC. This can be explained by the politicization of the cult of Venus, particularly as the divine ancestress of the gens Iulia. In combination with the importance of Venus' consort Mars as the father of Romulus, these divinities invited allegorization as Empedoclean "Love" and "Strife" governing the four elements as a symbol of Roman, and especially Julian, governance of world affairs. On the other hand, both before and after the gens Iulia was in its political ascendancy (i.e. for most of the Republican period before the rise of Julius Caesar himself, and for most of the Imperial period after the fall of the Julio-Claudian dynasty, if not indeed after the end of Augustus' reign, i.e. that of the most self-consciously "Julian" of emperors), the particular relevance of Venus/Love and Mars/Strife to major political interests, and so a specifically Empedoclean conception of Roman global hegemony, held much less appeal. In view of these facts, it makes sense to assess apparently Empedoclean motifs in Latin poetry not as essential or even conventional ingredients of any particular genre, but in terms of their relevance to prevailing cultural circumstances at any given time.

\section{INDEX}

Mots-clés: Accius, Augustus, Camillus, Concordia, Empedocles, Ennius, Epic, Flavian, Harmony, Julio-Claudian, Julius Caesar, Livius Andronicus, Lucilius, Lucretius, Naevius, Opimius, Ovid, Pompeius, Sulla, Venus, Venus Erycina, Venus Genetrix, Venus Victrix 